\title{
Effect of a Formalin Stress on the Adrenal Function of the Domestic Pigeon (Columba livia)
}

\author{
Sharmila Dasadhikari Agarwal* and Bandana Guha*
}

\begin{abstract}
The present study reveals that in domestic pigeons the glandular epinephrine (E) storage is higher in the morning than in the evening. Formalin administration in pigeons depleted the adrenomedullary content of $\mathbf{E}$ with elevation of blood sugar in the morning only. The glandular norepinephrine (NE) remained unaffected after formalin stress both in the morning and in the evening.
\end{abstract}

Stress related changes in the adrenal glands of birds are well documented (Harvey et al. 1984). It has already been established that initially, stressors cause stimulation of the sympathetic nervous system which results in rapid release of catecholamines (CAM) from sympathetic nerve terminals into the peripheral circulation. This is accompanied by CAM depletion, especially NE from the chromaffin cells of the adrenal medulla of birds (Rees et al. 1984). In this connection it may be pertinent to mention that Assenmacher pointed out that species-wise differences in the $\mathrm{E}$ and $\mathrm{NE}$ possibly lead to varying responses to stressors in birds (Assenmacher 1973). Stimulation of adrenal cortical activity also occurs during stress, which may in turn promote adrenomedullary activation (Harvey et al. 1984).

The occurrence of diurnal fluctuation in the adrenal cortical function has been recorded in some diurnally active birds, like the Japanese quail and duck (Boissin and Assenmacher 1968). The plasma and adrenal corticosterone levels were observed to reach a peak towards the end of night and become progressively low during day hours (Boissin and Assenmacher 1968). However, though the diurnal variation of adrenal cortical activity is well known, the nature of such changes of the adrenomedullary hormones is decidedly lacking in birds.

Further, to the best of our knowledge, stress induced alterations in the diurnal rhythmicity of the pigeon adrenal hormones have not been reported so far. In view of this, an experimental study using formalin, a known chemical stressor of pigeon adrenal gland (Bhattacharyya et al. 1972) was undertaken in the present investigation.

\section{Materials and Methods}

Young adult domestic pigeons of both sexes, body weights ranging between 200-250 gms were purchased from the local bird dealer in the months of November and December, when the day length at Calcutta is less than 11 hours. The animals were acclimatized to the laboratory conditions for seven days and were fed ad libitum. They were divided into

Received 10 December 1988. Accepted 28 August 1991.

* Histophysiology Laboratory, Department of Zoology, University of Calcutta, 35 Ballygunge Circular Road, Calcutta 700 019, India. 
Table 1. Effect of formalin stress on adreno-cortico-

\begin{tabular}{|c|c|c|c|c|c|}
\hline \multirow{2}{*}{ Group } & \multirow{2}{*}{ Treatment } & \multicolumn{2}{|c|}{ Blood Sugar (mg\%) } & \multicolumn{2}{|c|}{ Corticosterone $(\mu \mathrm{g} / \mathrm{gm})$} \\
\hline & & Morning & Evening & Morning & Evening \\
\hline Control & - & $\begin{array}{c}257.71 \pm 14.13 \\
(8)\end{array}$ & $\begin{array}{c}212.15 \pm 18.32 \\
(7)\end{array}$ & $\begin{array}{l}5.32 \pm 1.14 \\
(7)\end{array}$ & $\begin{array}{c}3.24 \pm 0.47 \\
(8)\end{array}$ \\
\hline Treated & $\begin{array}{l}1 \mathrm{ml} 10 \% \text { formalin } \\
\text { intramuscularly }\end{array}$ & $\begin{array}{c}474.72 \pm 41.09 \\
(7) \\
<0.001\end{array}$ & $\begin{array}{c}275.90 \pm 15.58 \\
(7) \\
<0.05\end{array}$ & $\begin{array}{c}4.67 \pm 0.91 \\
(7) \\
\text { N.S. }\end{array}$ & $\begin{array}{c}5.30 \pm 1.41 \\
(6) \\
\text { N.S. }\end{array}$ \\
\hline
\end{tabular}

Figures in parentheses indicate the number of birds used.

M, Morning; E, Evening. * Mean \pm Standard Error. N.S., Not significant.

separate experimental groups. Each bird in the first experimental group was injected with $1 \mathrm{ml}$ of $10 \%$ formalin intramuscularly in the morning $(8.00 \mathrm{a} . \mathrm{m}$.). The animals in the second experimental group were subjected to similar stress in the evening (6.00 p.m.). Separate groups of untreated birds were used as controls for the two experimental groups.

Ten minutes after formalin administration, $0.2 \mathrm{ml}$ of blood was collected from the wing vein of all the birds for blood sugar estimation following the method of Nelson and Somogyi (Oser 1965). The experimental and control birds were autopsied by cervical dislocation and adrenals were immediately dissected out, weighed and processed for corticosterone and catecholamines estimation. The catecholamines and corticosterone were estimated spectrofluorometrically in all groups (Laverty and Taylor 1968, Glick et al. 1964). Statistical analysis was carried out by means of Student's ' $t$ ' test.

\section{Results}

The quantitative experimental data have been tabulated in Table 1. The adrenomedullary epinephrine decreased in the morning but not in the evening after formalin injection. Blood sugar increased both in the morning and evening the same treatment. The increase in blood glucose level was significantly more in the morning than in the evening (see Table 1).

In the present investigation both control $\mathrm{E}$ and $\mathrm{NE}$ values showed significant variations between the morning and afternoon. The adrenomedullary NE values were not significantly altered during stress. In untreated birds, the glandular corticosterone contents seemed to be higher in the morning than afternoon. However, when the birds were exposed to formalin stress, our data show no statistically significant change in adrenal corticosterone level both in the morning and evening.

\section{Discussion}

Interestingly enough our results show that a diurnal variation exists in the adrenal $\mathrm{E}$ content of pigeons. Hence a perusal of Table 1 indicates that in pigeons the control values of glandular $\mathrm{E}$ is considerably higher in the morning than in the evening. In birds, stress 
medullary responses in the domestic pigeon (Columba livia).

\begin{tabular}{|c|c|c|c|c|c|}
\hline \multicolumn{2}{|c|}{ Epinephrine $(\mu \mathrm{g} / \mathrm{mg})$} & \multirow{2}{*}{$\begin{array}{c}\% \text { release } \\
\mathbf{M} \text { vs. } \mathrm{E}\end{array}$} & \multicolumn{2}{|c|}{ Norepinephrine $(\mu \mathrm{g} / \mathrm{ml})$} & \multirow{2}{*}{$\begin{array}{l}\% \text { release } \\
\mathrm{M} \text { vs. } \mathrm{E}\end{array}$} \\
\hline Morning & Evening & & Morning & Evening & \\
\hline $\begin{array}{c}1.51 \pm 0.18 \\
(7)\end{array}$ & $\begin{array}{c}0.79 \pm 0.07 \\
(7)\end{array}$ & 47.40 & $\begin{array}{c}0.65 \pm 0.06 \\
(7)\end{array}$ & $\begin{array}{c}0.37 \pm 0.01 \\
(8)\end{array}$ & 42.28 \\
\hline $\begin{array}{c}0.41 \pm 0.05 \\
(6)\end{array}$ & $\begin{array}{c}0.57 \pm 0.12 \\
(6)\end{array}$ & & $\begin{array}{c}0.48 \pm 0.07 \\
(6)\end{array}$ & $\begin{array}{c}0.37 \pm 0.07 \\
(6)\end{array}$ & 22.47 \\
\hline$<0.001$ & N.S. & & N.S. & N.S. & \\
\hline
\end{tabular}

induced adrenal responses have been studied by a number of investigators, but the reports are often conflicting (Harvey et al. 1984). Zachariasen and Newcomer (1974) observed a significant decrease in glandular $\mathrm{E}$ and $\mathrm{NE}$ levels following physical activities in chicken and quail. Earlier investigators in this laboratory have also revealed that the avian adrenal medullae react uniformly to all acute stressors by releasing NE (Ghosh 1980). Bhattacharyya et al. (1972) however reported rise in glandular $\mathrm{E}$ following immobilization and amphenone administration in pigeons. The present study reveals a significant depletion of adrenal $\mathrm{E}$ and elevated blood sugar level following acute formalin stress, only in the morning while the magnitude of stress response was insignificant in the evening.

It has been already established that stress causes increased adrenocortical activity in birds. Elevated plasma corticosterone and high adrenal corticosterone content result from increased rate of corticosterone production (Harvey et al. 1984). In pigeons Bhattacharyya and Ghosh (1972) also observed increased adrenal corticosterone level after application of formalin stress. Surprisingly however in the present experiment, significant formalin stress related changes in the glandular corticosterone level have not been observed. Since adrenocorticosterone release is dependent on the nature, severity and duration of stressors (Harvey et al. 1984) the absence of any alteration in the adrenal corticosterone value may be due to the short (ten minutes) formalin stress duration in the present investigation.

Hence taking all the above findings in account, the stress related diurnal changes of avian adrenal gland needs further explorative investigation in more avian species.

\section{Acknowledgement}

The authors are indebted to Professor Asok Ghosh for his valuable guidance. This work was supported by a Research Associateship (No. F. 16-99/85/RF-I) and UGC Special Assistance Programme in Zoology (No. F. 14-7/77, SRI), both granted by the University Grants Commission, New Delhi. 


\section{References}

Assenmacher, I. 1973. The peripheral endocrine glands. In: Avian Biology. Eds. D. S. Farner, J. R. King and K. C. Parker. Vol. 3, p. 104. Academic Press, New York.

Bhattacharyya, T. K. \& Ghosh, A. 1972. Cellular modification of interrenal tissue induced by corticoid therapy and stress in three avian species. Am. J. Anat. 133: 483-494.

Bhattacharyya, T. K., Ray, B. \& Manna, C. 1972. Participation of adrenocortical and medullary hormones during stress in intact and amphenone treated pigeon. Endocrinol. Exp. (Bratislava) 6: 179-186.

Boissin, J. \& Assenmacher, I. 1968. Rhythms circadiiens des tanx Sanguin et surrenalien de la corticosterone chez la Caillie. Comp. Rend. Acad. Sci. 267: 2193-2196.

Ghosh, A. 1980. Avian adrenal medulla: structure and function. In: Avian Endocrinology. Eds. A. Epple and M. H. Stetson. pp. 301-316. Academic Press, New York.

Glick, D., D. V. Redlich \& Levine, S. 1964. Fluorometric determination of corticosterone and cortisol in 0.02$0.06 \mathrm{ml}$ of plasma or submilligram samples of adrenal tissue. Endocrinology 74: 653 .

Harvey, S., Phillips, J. G., Rees, A. \& Hall, T. R. 1984. Stress and adrenal function. J. Exp. Zool. 232: 633645.

Laverty, R. \& Taylor, K. M. 1968. The fluorometric assay of catecholamines and related compounds: Improvements and Extensions to the Hydroxyindole Technique. Annal. Biochem. 22: 269-279.

Oser, B. L. 1965. In: Hawk's Physiological Chemistry. McGraw Hill, pp. 1031-1032. New York.

Rees, A., Hall, T. R. \& Harvey, S. 1984. Adrenocortical and adrenomedullary response of fowl to tread mill exercise. Gen. Comp. Endocrinol. 55: 488-492.

Zachariasen, R. D. \& Newcomer, W. S. 1974. Phenylethanolamine N-methyl transferase activity in the avian adrenal following immobilisation or adrenocorticotrophin. Gen. Comp. Endocrinol. 23: 193-198.

\section{イエバト (Columba livia) におけるホルマリンストレスの副腎機能に及ぼす影響}

イエバトの副憼中のエビネフリン量は, 朝の方が夕方よりも多い。ホルマリンストレスでは, 朝のエビネ フリン量は減少するが, 夕方では減少しない。血糖も朝の方が多い。ホルマリンストレスで, 血糖は朝多と もに減少する。ノルエピネフリンの副腎含量は朝は夕方よりも多い。しかし，ホルマリンストレスで，朝夕 其に有意には減少しない。コルチコステロンの含量は朝と夕方では有意な差はなく，またホルマリンスト レスで有意な変化はホさない。

Agarwal, S. D., Guha, B.; カルカッ夕大学動物学教室組織生理学研究室 